\section{Graphic Symbol Based Interactive Animation Development Process for Deaf or Hard of Hearing Students}

\author{
Lokman Şılbıra, Asiye Mevhibe Coşarb, Yasemin Kartalc, \\ Taner Altun ${ }^{d, *}$, Murat Atasoye, Gülşen Özçamkan-Ayaz ${ }^{f}$
}

$\begin{array}{ll}\text { Received: } & \text { 12 September } 2019 \\ \text { Revised: } \quad & 4 \text { February } 2020 \\ \text { Accepted: } & 2 \text { March } 2020 \\ \text { ISSN: } 1307-9298 \\ \text { Copyright @ IEJEE } \\ \text { www.iejee.com }\end{array}$

DOI: $10.26822 /$ iejee.2020459466

\begin{abstract}
This study examined the development process of graphic symbol-based animations for enhancing literacy skills of deaf or hard of hearing students $(\mathrm{D} / \mathrm{HH})$. Participants of the study consisted of two teachers and seven students studying in the third and fourth grade in a primary school for hard of hearing. As a result of the studies conducted throughout the fall and spring semesters, animation environments based on graphic symbols were developed. Within the framework of the design-based research methodology, development studies were followed by revisions. Revision studies were conducted in line with the data obtained from the interviews and observation notes that continued throughout the practices. A content analysis was utilized to examine the data obtained through interview and observation. It has been determined that; in the animations each sentence should be presented clearly and it may be paused if necessary, minor details and the dormant objects in the background should be removed, animations of actions should be standardized, and fonts in animations should match the writing style used by the students in the animations. As a result of the study, a design guide for graphic symbols-based animations for $\mathrm{D} / \mathrm{HH}$ were developed for the researchers in line with the acquired results
\end{abstract}

Keywords: Deaf or Hard of Hearing (D/HH), Education, Symbols-Based Animation

\section{Introduction}

The inability to perceive auditory signals coming from the environment and the inability to respond to signals because of hearing loss negatively affect the social and language development of individuals (Bowers, Dostal, Wolbers, \& Graham, 2018; Cavkaytar \& Diken, 2005; MEB, 2006). Developmental problems caused by hearing loss affect the academic achievement, the development of perceptual skills, and the cognitive progress of students negatively (Akmeşe, Sezgin, \& Ögüt, 2019; Rudner et al., 2015; Tüfekçioğlu, 1998). It is reported that a significant majority of deaf or hard of hearing $(\mathrm{D} / \mathrm{HH})$ students lag at least five years behind compared with their peers in the educational environment because of the problems they face with regard to literacy education (Kyle \& Harris, 2006). It is also stated that even the literacy skills of adults do not exceed the fourth-grade level (Dillon, de Jong, \& Pisoni, 2012).

Studies conducted on $\mathrm{D} / \mathrm{HH}$ students asserted that they are deprived of natural language inputs (Scott, Goldberg, McDonald-Connor, \& Lederberg, 2019; Lederberg, Schick \& Spencer, 2013; Pınar, 2006; Tüfekçioğlu, 1998) and therefore experienced problems in critical periods of language acquisition (Scott \& Dostal, 2019; Marschark et al., 2009), that their communication with their families is limited (Turnbull, Turnbull, Wehmeyer, \& Shogren, 2013), that they do not have adequate and appropriate educational and instructional programs (Turnbull et al., 2013), and that they frequently miss social cues in their surroundings (Cole, Cutler, Thobro, \& Haas, 2009). It is recommended that learning environments be developed that will be designed with consideration of the special needs of the D/HH students, will help eliminate their disadvantageous situations and will provide for equality of opportunity in education (Cruz, 2013).

When the learning environment is being designed for students with hearing problems, it requires a more difficult process, compared with their typical peers. Studies conducted for the evaluation of the learner characteristics of students with hearing problems reveal that these students can be dealt with as visual learners (Chen, 2014) and that the use of visual materials is important (Nikolaraizi, Vekiri, \& Easterbrooks, 2013; Reitsma, 2009). It is necessary to place particular importance on the choice and presentation of visual stimulants in materials to be developed for D/HH students, whose attention is generally in a visual direction, and who can more easily notice visual stimulants than their peers (Türköz-Sarp, 2013). At this point, researchers who conduct technology-supported studies in the field of special education described technology as a universal equaliser (Amiel \& Reeves, 2008; Ellis \& Kent, 2011; Foley \& Ferri, 2012; Singh \& Mahapatra, 2019). Multimedia materials supported with information and communication technologies presenting information in a visual format (Şılbır, 2011; Hoffman, \& Wang, 2010; Luckner \& Cooke, 2010) and allowing individuals to more actively use multiple contents and contexts in their cognitive processes are seen as an opportunity for the education of the D/HH students (Marschark \& Knoors, 2012; Snoddon, 2010; Ünlüer, 2010), because these types of materials (videos, images, animations, graphic symbols) have a rich interaction of content and are easily expressed linguis-

\footnotetext{
a Lokman Şılbır, Trabzon University, Fatih Faculty of Education, Department of Computer Education \& Instructional Technology, Trabzon, Turkey E-mail: lokmansilbir@trabzon.edu.tr

Asiye Mevhibe Coşar, Karadeniz Technical University, Faculty of Literature, Department of Turkish Language and Literature, Trabzon, Turkey. E-mail: mcosar@ktu.edu.tr

cYasemin Kartal, Trabzon University, Fatih Faculty of Education, Department of Computer Education \& Instructional Technology, Trabzon, Turkey. E-mail: yaseminkaral@trabzon.edu.tr

d,* Corresponding Author: Taner Altun, Trabzon University, Fatih Faculty of Education, Department of Elementary Education, Trabzon, Turkey E-mail: taltun@trabzon.edu.tr

Murat Atasoy, Trabzon University, Fatih Faculty of Education, Department of Computer Education \& Instructional Technology, Trabzon, Turkey. E-mail: murat.atasoy@trabzon.edu.tr

Gülşen Özçamkan Ayaz, Karadeniz Technical University, Faculty of Literature, Department of Turkish Language and Literature, Trabzon, Turkey. E-mail: gulsenozcamkans@hotmail.com
} 
tically (Gentry, Chinn, \& Moulton, 2004). Materials supported with visuals are helpful in ensuring that $\mathrm{D} / \mathrm{HH}$ students more easily understand the words, increasing their literacy skills, and earning them motivation for reading (Nikolaraizi \& Vekiri, 2012, Paudyal, Banerjee, Hu, \& Gupta, 2019). That is why it is necessary to pay attention to the choice of visuals to be used in the education of the $\mathrm{D} / \mathrm{HH}$, where the use of visuals is prioritised. It is important that these visuals that will be used are prepared for the individual characteristics and educational needs of $\mathrm{D} / \mathrm{HH}$ students.

Graphic symbols are defined as figures that can be perceived visually and transmit information independently from the language (ISO 17724:2003). Fuller and Lloyd (1991), who studied graphic symbols, emphasised the term iconicity as being nearly transparent between a plane with one transparent side and one opaque side. Previously conducted studies show that iconicity is effective for the understanding of graphic symbols by D/HH students (Mollink, Hermans, \& Knoors, 2008; Tolar, Lederberg, Gokhale, \& Tomasello, 2008). The studies on the current graphic symbol systems revealed that they used simple colours (generally black and white), avoiding complex drawings, and graphic symbols contained only one concept (Tucker-Cohen, Allgood, Heller, \& Castelle, 2001; Trudeau, Sutton, Dagenais, De Broeck, \& Morford, 2007). Some examples of graphic symbol systems are seen in Figure 1.

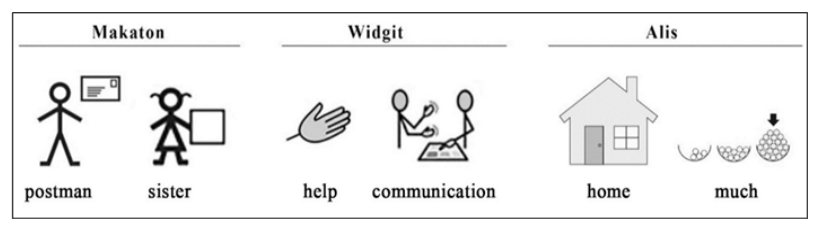

Figure 1. Examples of Graphic Symbol Systems

Besides the graphic symbols, multimedia materials such as video, animation, and AR books are also used in educational environments of $\mathrm{D} / \mathrm{HH}$ students. When the studies of these materials are examined, it is seen that different features are used in different studies but not standardized. In the animations, using simple drawings, audio, and subtitle support is proposed (Cambra, Penacchio, Silvestre, \& Leal, 2014; Lányi Váry, Sik, Nemetz, \& Geiszt, 2004). Furthermore, many researchers evaluated the use of a sign language translation over an educational material as an animation (Jemni, Elghoul, \& Makhloufet, 2007; Kaneko, Hamaguchi, Doke, \& Inoue, 2010 Kipp, Heloir, \& Nguyen, 2011; Kourbetis, 2013). Zainuddin, Zaman and Ahmad (2010) determined that when taking into consideration the visual learning needs of students, AR book materials should include the following features: colourful and simply drawn graphic symbols, short texts, texts presented with appropriate graphics, an environment supported with sign language, and 2D or 3D models. When considering the design recommendations made for the videos, it was reported that subtitles needed to be added to the videos and that understandable and simple texts needed to be used (Debevc, Kosec, \& Holzinger, 2010; Jensema, Danturthi, \& Burch, 2000; Talaván, 2019). On the other hand, in independent studies that referred to multimedia materials, iconic graphic designs, providing audio support, presenting text and visuals together, context-essential content, text-symbol-sign language compliance, adding subtitles, user-centred design, and the inclusion of sign language translations was recommended (Gatti, Matteucci, \& Sbattella, 2004; Gentry et al., 2004; Mayer \& Moreno, 2003; Petrie, Weber, \& Fisher, 2005; Techaraungrong, Suksakulchai, Kaewprapan, \& Murphy, 2017). The design recommendations of the different studies in the literature are summarised in Table 1.

In these studies, different design features or different components are mentioned for animations. However, it is unclear whether these design features or components should be used together. There is also no evidence regarding how the designs should be structured in the case of the combined use of these components. At this point, it is necessary to determine the components and design features of the animations to be used in the educational environments of hearing-impaired individuals.

Table 1. Materials and Design Recommendations Developed for the Hearing Impaired.

\begin{tabular}{|c|c|c|c|c|}
\hline $\begin{array}{l}\text { Design } \\
\text { Suggestion }\end{array}$ & Animation & AR Book & $\begin{array}{l}\text { Multimedia } \\
\text { materials }\end{array}$ & Video \\
\hline Simple drawings & $x$ & $x$ & & \\
\hline $\begin{array}{l}\text { Iconic graphic } \\
\text { designs }\end{array}$ & & & $x$ & \\
\hline Colourful visuals & & $x$ & & \\
\hline $\begin{array}{l}\text { Sound } \\
\text { support }\end{array}$ & $x$ & & $x$ & \\
\hline $\begin{array}{l}\text { Presenting text } \\
\text { and visuals } \\
\text { together }\end{array}$ & & & $x$ & \\
\hline $\begin{array}{l}\text { Context-based } \\
\text { contents }\end{array}$ & & $x$ & $x$ & \\
\hline $\begin{array}{l}\text { Text, symbols, } \\
\text { and sign language } \\
\text { compatibility }\end{array}$ & & $x$ & $x$ & \\
\hline $\begin{array}{l}\text { Using } \\
\text { subtitles }\end{array}$ & $x$ & & $x$ & $x$ \\
\hline $\begin{array}{l}\text { Understandable } \\
\text { and } \\
\text { simple texts }\end{array}$ & & $x$ & & $x$ \\
\hline $\begin{array}{l}\text { User-centred } \\
\text { design }\end{array}$ & & & $x$ & \\
\hline $\begin{array}{l}\text { Using sign- } \\
\text { language } \\
\text { translation }\end{array}$ & $x$ & $x$ & $x$ & \\
\hline
\end{tabular}

This study is the first step towards the identification of the characteristics that interactive animations developed for the educational environments of D/HH students should have. The goal of the research is to identify which design criteria graphic symbol based animations should possess in the literacy education of D/HH students. In this framework, the response was sought in this study to the question, "Which design criteria should graphic symbol based interactive animations used in the literacy education of D/HH students possess?"

\section{Methodology}

\section{Research Design}

The method of the research was shaped in the framework of design-based research (DBR) to optimise the operation in the application of the product to be developed. DBR provides guidance for the development, clean of errors, of a product to emerge by cyclically checking the material development processes (Amiel \& Reeves, 2008; Collins, Joseph, \& Bielaczyc, 2004; Kuzu, Çankaya, \& Mısırlı, 2011). It is reported that the gap caused by the distance from the real-life practices in the field of education is also the reason for the loss of confidence in educational research (The Design-Based Research Collective, 2003). At this point, the goal of the DBR is to manage the interaction between educational research and real-world problems (Amiel \& Reeves, 2008).

The study aims to develop the animations to be used in the learning environments of $\mathrm{D} / \mathrm{HH}$ students under real-world conditions and to develop the most suitable product. In this respect, the first designs for animations with the views of teachers and the evaluations of field experts were developed 
as a result of the needs analysis. After the first design of animation was developed, in line with the suggestions of teachers, animations for Turkish Language, Life Sciences, Social Sciences, and Physical Sciences lessons were developed.

In DBR, applicators are seen as a valuable partner in the determination of problems and the production of solutions to these problems (Amiel \& Reeves, 2008). In this context, for each application conducted, recommendations for corrections and changes were received by conducting interviews with the application classroom teachers. The researchers conducted in-class observations for the purpose of identifying the problems encountered in the in-class applications of the animations.

\section{ALIS Graphic Symbol Dictionary}

The project, briefly called ALis with the representation of the first letters in Turkish spelling, is an alternative communication system developed for D/HH. TUBITAK was supported with the project number $110 \mathrm{~K} 257$ to create ALis dictionary for the hearing impaired individuals. The visual channel is very important for the hearing impaired individuals because of the disruptions in the auditory channel. However, during the use of the visual channel, students' distraction and turning to different points appear as undesired situation. At this point, the ALis dictionary has been specially developed using graphic symbols purged from details. Graphic symbols, of which standardization studies have been completed, are presented to the use of individuals with hearing disabilities and those concerned. It was initially composed of a total of 843 graphic symbols in 24 categories, and it continues to be developed by the addition of new graphic symbols (www.alis.org.tr).

Table 2. Demographic Information About the Students

\begin{tabular}{|c|c|c|c|c|c|c|c|}
\hline Student Code & $\mathrm{ST}-1$ & $\mathrm{ST}-2$ & $\mathrm{ST}-3$ & ST-4 & ST-5 & ST-6 & ST-7 \\
\hline Age & 10 & 10 & 9 & 11 & 10 & 11 & 11 \\
\hline Gender & $\mathrm{F}$ & M & $\mathrm{F}$ & $\mathrm{M}$ & M & $\mathrm{F}$ & $\mathrm{F}$ \\
\hline Hearing Loss & $91+d B^{*}$ & $70 \mathrm{~dB}$ & $91+d B^{*}$ & $91+d B^{*}$ & $72 \mathrm{~dB}$ & $71-90 \mathrm{~dB}$ * & $71-90 d^{*}$ * \\
\hline
\end{tabular}

*The medical report provided information as high or very high hearing loss.

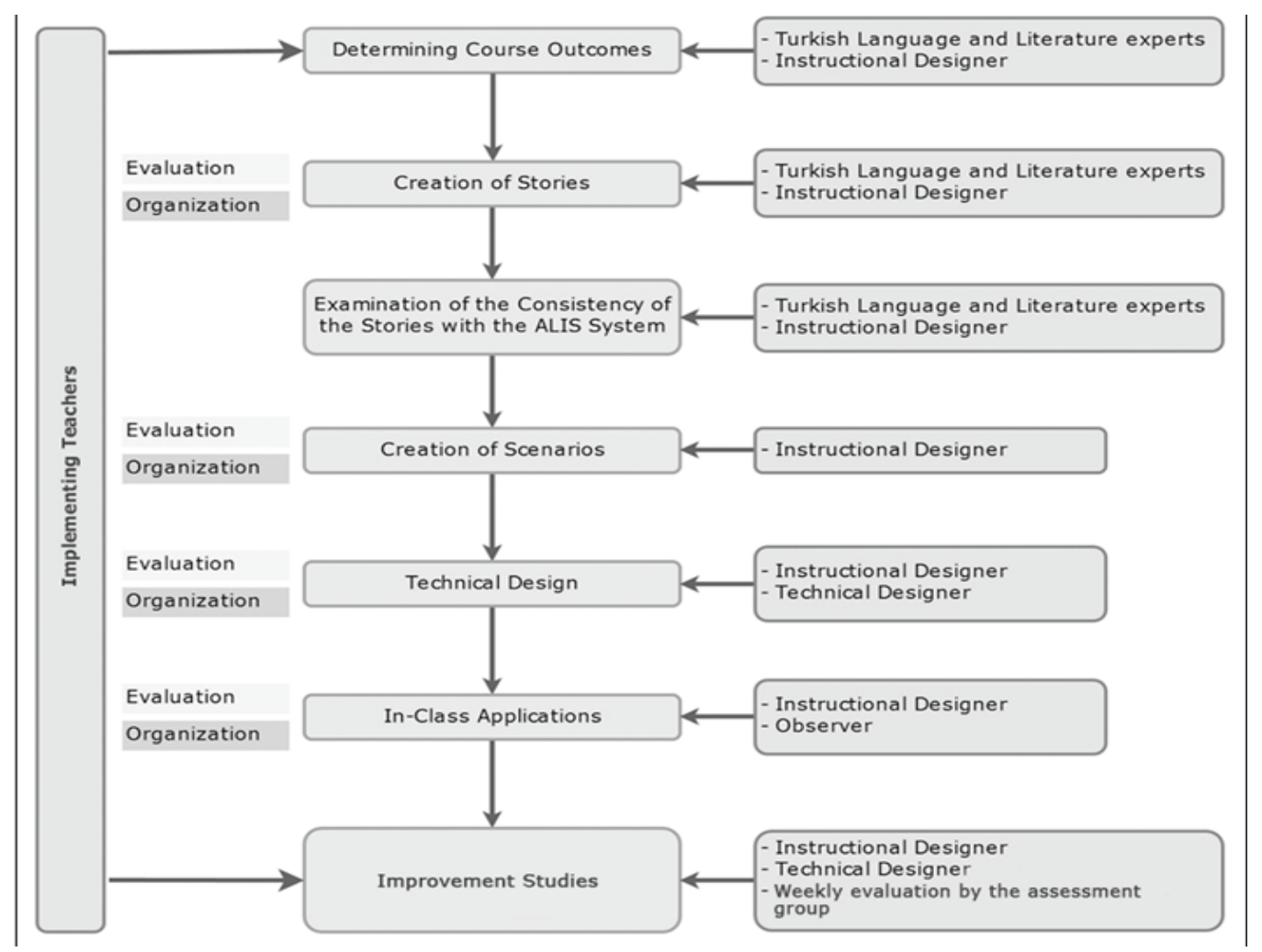

Figure 3. Animation Development Process
Figure 2 presents examples of the graphic symbols found in the ALIS dictionary.

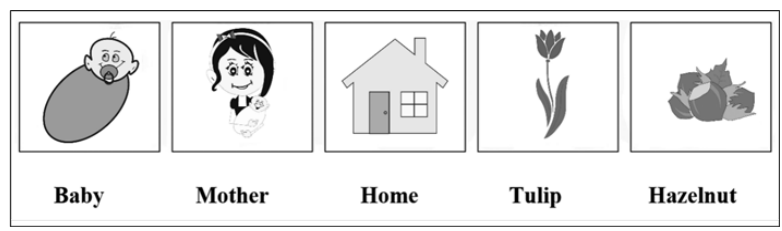

Figure 2. Examples of the graphic symbols found in the ALIS dictionary

\section{Study Group}

The participants in this study were chosen through the purposeful sampling (Patton, 2014) method, considering the speculative framework, objective, and research problem of the research. In this context, participants of the research are composed of two classroom teachers who work in a primary school for the hard of hearing and seven students. Teachers who graduated from the Department of Special Education were coded as T1 and T2. T1, the third-grade teacher, has ten years of classroom experience while T2, the fourth grade teacher, has nineteen years of classroom experience at the school for the $\mathrm{D} / \mathrm{HH}$.

In addition, seven students in third and fourth grades were included in the study. All students have advanced (70 - 90 $\mathrm{dB}$ ) or very advanced $(91+\mathrm{dB})$ hearing loss. Table 2 summarizes the demographic information for the research group. 
Table 3. Applications where revision requests for the animations emerged

\begin{tabular}{|c|c|c|c|c|c|c|c|c|c|c|c|c|c|c|c|c|c|c|c|c|c|c|}
\hline Application Period & & & & $\mathrm{Fal}$ & Sen & este & & & & & & & & & & ring & eme & ter & & & & \\
\hline Number of application & 1 & 2 & 3 & 4 & 5 & 6 & 7 & 8 & 9 & 10 & 11 & 12 & 13 & 14 & 15 & 16 & 17 & 18 & 19 & 20 & 21 & 22 \\
\hline $\begin{array}{l}\text { Revision requested } \\
\text { applications }\end{array}$ & $\mathrm{R} 1$ & R2 & R3 & R4 & & & R5 & & & & & & & & & R6 & & R7 & & & & \\
\hline
\end{tabular}

\section{Implementation Process}

The research was carried out within the scope of studies supported by The Scientific And Technological Research Council of Turkey (TÜBITAK) (Grant No. 113K717). In this context, field experts in the project team were tasked with the development and evaluation processes. The animation development process was conducted with the collective work of classroom teachers, an instructional design expert, classroom instruction experts, and Turkish language and literature field experts. Figure 3 summarizes the steps in the animation development process and the field experts involved in this process.

When Figure 3 is examined, this process, which started with the classroom teachers' identification of the course outcomes, was completed with the improvement studies. Application teachers have been involved in the determination of course outcomes, development of story texts for course outcomes, the creation of scenarios and the evaluation in the whole process activities. The experts in the field of Turkish language and literature have developed the stories by considering the ALIS dictionary. Afterwards, the scenarios for the stories were created by the cooperation of classroom teachers and instructional designers. The instructional design field experts turned these scenarios, which were created in the context of stories, into animations at the end of the technical design process. By reorganizing the animations that emerged in the scope of the views and recommendations of the classroom teachers and other field experts, the first applications in the classroom setting were carried out. By evaluating the problems encountered during the in-class applications, the final form was given to the animations after conducting the necessary revision studies. Table 3 presents the applications for which revision requests emerged for the animations used in this process.

When Table 3 is examined, it is seen that a revision request arose after each of the first four applications. The final revision request was received in the $18^{\text {th }}$ application. All animations developed after these were developed with consideration of these requests. The revision process was completed at this point. By re-evaluating the old animations up to the 18th application for which the final revision request was received, the revision suggestions that were left incomplete were completed for these animations.

\section{Data Collection Tools and Data Collection Process}

In the implementation, qualitative data collection techniques were used to provide in-depth and detailed data needed by DBR. Qualitative approaches, which are frequently used in the field of special education (Pugach, 2001), are considered valuable in terms of providing researchers in this field with the opportunity to examine the case within the context of the research (Stoner, 2010; Brantlinger, Jimenes, Klingner, Pugach, \& Richardson, 2005). In this context, observation and interview techniques were used within the framework of the research. Observations were realized by the researchers following the practices in the class in the role of participant observer (Büyüköztürk, Kılıç-Çakmak, Akgün, Karadeniz, \& Demirel, 2014). During the two academic years, observations were made for a total of 43 applications. The researchers recorded each observation in detail as an observation note about the application (design, content, student suitability, etc.) by specifying the date, time, application class and application name. In addition, observations were recorded using photographs, videos or sound recordings (Denzin \& Lincoln, 2000). A photo of the observation process of the lesson conducted with the animation of the "Birthday" story applied in the third grade is presented in Figure 4.

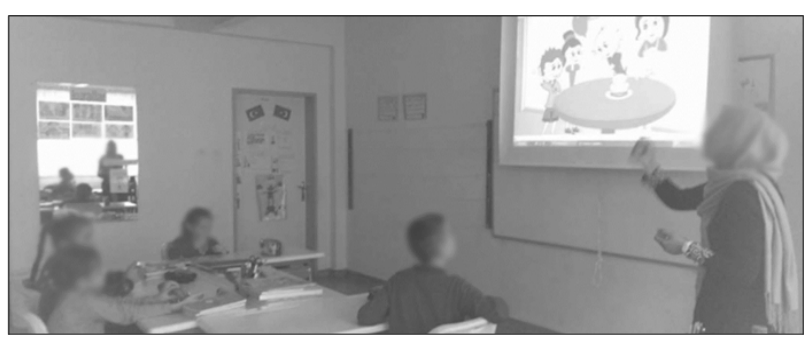

Figure 4. A photograph of the observation process of the class conducted with the animation for the "Birthday" story implemented in the third-grade class.

The interviews were conducted before and after each application with two application teachers, in the form of a non-structured interview. In the development studies carried out cyclically within the framework of the DBR, unstructured interviews were conducted to determine the opinions, suggestions and requests of the application teachers. The focus of the questions used in these interviews was to determine the properties that the animations developed should have. Interview questions and rankings are not fixed in unstructured interviews. It can develop during the interview. In this way, it is aimed to collect rich and sufficient information (Büyüköztürk et al., 2014). The data obtained are given as a quotation in the findings section.

\section{Data Analysis}

Field experts, technical designers, special education and instructional technology experts should act together in the selection and integration of technologies to be used in the education of disabled people (Véliz et al., 2016; Akay, Uzuner, \& Girgin, 2014; Karal \& Çiftçi, 2008). In this context, the study conducted with the DBR method, it was important to analyse the data obtained via interviews and observations by technical designers, special education and instructional technology experts during consecutive applications. Using the evaluations after each application made the data analysis process more valuable. To analyse and evaluate the data obtained after each application, an evaluation group consisting of researchers and teachers in the research group of $113 \mathrm{~K} 717$ was formed. In the evaluation group, there were four instructional designers, two Turkish language and literature specialists, one classroom teacher specialist, and two teachers. Evaluation group members in different areas of expertise provide their opinions, suggestions and contributions about the practices carried out in their own area of expertise. The decisions taken by the evaluation group are discussed, and the final shapes are given to the designs in the animations. Demographic information of the experts in the evaluation group is given in Table 4.

In the practices carried out during the two academic years, weekly or two-weekly meetings were held to exchange views 
Table 4. Demographic Information of the Experts in the Evaluation Group

\begin{tabular}{lll}
\hline Area of Expertise & \multicolumn{1}{c}{ Institution of Employment } & Title \\
\hline Instructional Design & Karadeniz Technical University (KTU) & Prof. Dr. \\
\hline Turkish Language and Literature & KTU & Prof. Dr. \\
\hline Basic/Classroom Education & KTU & Assoc. Prof. Dr. \\
\hline Instructional Design & KTU & Assist. Prof. \\
\hline Instructional Design & KTU & Assist. Prof. \\
\hline Instructional Design & KTU & Res. Asst. \\
\hline Turkish Language and Literature & KTU & Res. Asst. \\
\hline Education of the D/HH & Primary School for the Hard of Hearing & Teacher \\
\hline Education of the D/HH & Primary School for the Hard of Hearing & Teacher \\
\hline
\end{tabular}

Table 5. Revision Process Carried Out Based on Chronological Order

\begin{tabular}{|c|c|c|}
\hline $\begin{array}{l}\text { Revision } \\
\text { No }\end{array}$ & Revision Suggestions & Completed Revisions \\
\hline 1. & $\begin{array}{l}\text { - There should be an explicit provision in the animation for each sentence in } \\
\text { the story. } \\
\text { - Objects that are small and eye-straining should be removed. }\end{array}$ & $\begin{array}{l}\text { - The animation was paused for each sentence. } \\
\text { Forward and backward buttons were added for } \\
\text { navigation after the pause. } \\
\text { - Little details in the animation and functionless } \\
\text { objects in the background were removed. }\end{array}$ \\
\hline 2. & $\begin{array}{l}\text { - Actions like thinking and speaking should be standardised in the anima- } \\
\text { tions. } \\
\text { - The writing font should be suitable for the children. }\end{array}$ & $\begin{array}{l}\text { - The demonstration within the animation of } \\
\text { actions like "thinking", "speaking", "taking", and } \\
\text { "giving" was standardised. } \\
\text { - The writing font was organised as a handwriting } \\
\text { font. }\end{array}$ \\
\hline 3. & - Punctuation marks should be provided. & $\begin{array}{l}\text { - Punctuation marks such as periods, commas, and } \\
\text { question marks were added to the animation. }\end{array}$ \\
\hline 4. & $\begin{array}{l}\text { - The number of words should be decreased for the two sentences, each } \\
\text { with seven words, in the story, or the sentences should be divided up. } \\
\text { - The flows of events in the stories should not be long because this leads to } \\
\text { inattentiveness in the students. }\end{array}$ & - Long flows of events in the animations were split. \\
\hline 5. & - The animation drawings should suit the current graphics. & $\begin{array}{l}\text { - Animation drawings suitable for the visuals found } \\
\text { in the ALIS dictionary were made. }\end{array}$ \\
\hline 6. & $\begin{array}{l}\text { - Sound effects and speaking sounds should be used in the animations. } \\
\text { - Environmental sounds should be added (e.g., alarm, dog bark, walking). } \\
\text { - The scene in the animation where the frog turns into the prince should use } \\
\text { magical sound effects to objectify the scene because it is quite abstract. }\end{array}$ & $\begin{array}{l}\text { - Environmental sounds were added to the anima- } \\
\text { tions. }\end{array}$ \\
\hline 7. & $\begin{array}{l}\text { - The animations were prepared in the form of three different media and } \\
\text { should be combined in a single platform, and the right to choose during the } \\
\text { application should reside with the user. }\end{array}$ & $\begin{array}{l}\text { - The demonstration of the text and graphic sym- } \\
\text { bol support in the animations was made optional } \\
\text { during the application. }\end{array}$ \\
\hline
\end{tabular}

about the applications. The data obtained from interviews and observations in the scope of the research were analysed by the evaluation group. Interview and observation records were presented to the evaluation group as a report after being transcribed by the researchers. After evaluating the criticism from the class teachers through this report by the evaluation group, the revision suggestions were made for the future animations.

\section{Findings}

The data acquired throughout the research were presented by following the steps of DBA. Especially the design characteristics of the developed learning environment were determined in light of the data acquired from the analysis step, and design revisions were later shaped with interview and observation data.

\section{Findings Regarding the Stages of Analysis}

Regarding the findings obtained, the first drafts of the learning environment to be developed were determined in the analysis stage of the research. Based on the data obtained from the implementing teachers, three different media designs have been proposed for in-class use of graphic symbol based animations for the students. These designs were planned in the form of three different media, namely, ani- mation $(A)$, animation-text $(A+T)$, and animation-text-graphic symbol $(A+T+G)$. Figure 5 shows the placement of animation, text and graphic symbols that will be used in the animations to be developed.

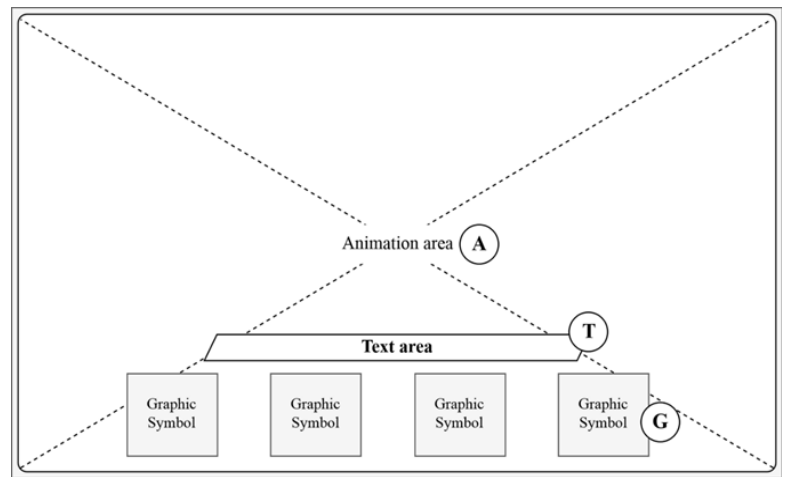

Figure 5. Placements on the screen of the first designs

When Figure 5 is examined, an image of the animation is found throughout the screen. Demonstrations with text and graphic symbols of the stories in the animations are positioned in the lower centre section of the screen. The contents of environments to be developed using this design were reported with consideration of the interviews conduct- 
ed with the implementing teachers and the individual characteristics of the students. It was decided that the stories to be used in the contents should be created within the framework of the course outcomes in the individualised academic plans in the Turkish, Life Sciences, Social Sciences, and Physical Sciences courses.

\section{Findings Relating to the Application and Evaluation Stages}

The revision studies for the animations developed in the scope of the study were made for fulfilling the needs that emerged with regard to the observations conducted in the in-class applications and the data from the unstructured interviews. The revision suggestions that emerged during the implementation process were put into practice after reviewing by the evaluation group. In this context, the revision process was completed in seven stages. Table 5 chronologically presents the revision process completed in these stages.

The observations of the researchers and the suggestions coming from the class teachers (Revision Suggestions) and the revision studies that the assessment group decided upon for these suggestions (Completed Suggestions) are seen in Table 5. The first round of revisions was conducted as a result of the evaluation of the interviews held with the implementing teachers for the first animations. In this context, it was stated by the teachers that each sentence should have an explicit provision in the animation. In this scope, the views of $\mathrm{T} 2$ are as follows:

"...case, event and place drawings should be easily perceived by the student." (T2-03.11.2014)

Another recommendation made after the first application was towards the elimination of small objects that strain the eyes. The interview between $\mathrm{T} 2$ and the researchers as follows:

"... all $\mathrm{D} / \mathrm{HH}$ children, the interns are preparing slides, wherever there's something unrelated, the child is inclined towards that 'Look, a ball.' We can remove these." (T2-03.11.2014)

The opinions were evaluated at the weekly meeting by the evaluation group. As a result of the assessment meeting, the feature of pausing was added to the animations so that each sentence could be understood in the animation. Forward and backward buttons were added to the right and left sides of the screen for navigation after a pause. It was also decided to remove small objects in the animation environment. In this respect, these suggestions were considered while developing the next animation. In the "Temiz Okul" (Clean School) animation, the sitting children and basketball court in the background shown in circles in Figure 7 were removed due to feedback. Also, the navigation buttons were added to the animations so that the animation could be continued after a pause. These changes to the "Temiz Okul" animation are shown in Figure 6.

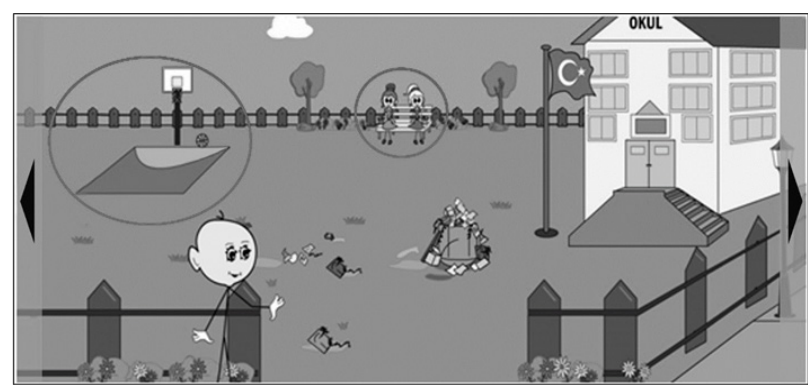

Figure 6. Example of the revision that was made in the "Temiz Okul" animation

The second round of revisions was made to standardise verbs such as "thinking" and "speaking" within the framework of the application carried out on 10.11.2014 and to write the fonts in animations according to the style that the students used. This situation is stated in the researcher's observation notes as follows:

"The teachers recommended standardising the demonstrations in the animations for actions like 'thinking' and 'speaking." (Observation Date: 10.11.2014)

In line with the recommendations obtained, the demonstrations in the animation of frequently used actions such as "thinking" and "speaking" were revised. In this framework, Figure 7 provides the demonstration of the action of "thinking" in the "Temiz Okul" animation before and after the revision. By revising the demonstration of the speaking sounds in the animations, a sound wave synchronised with mouth movements was added as long as the characters spoke. Figure 8 presents a screenshot of an example animation regarding the revision of speaking sounds in the animations.
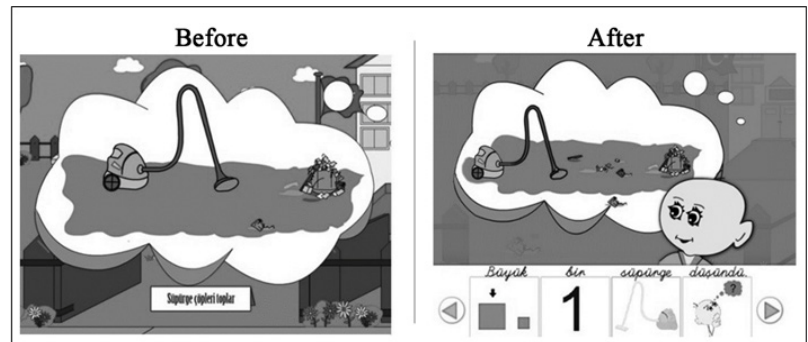

Figure 7. The demonstration before and after the revision in the "Temiz Okul" animation for the act of "thinking"

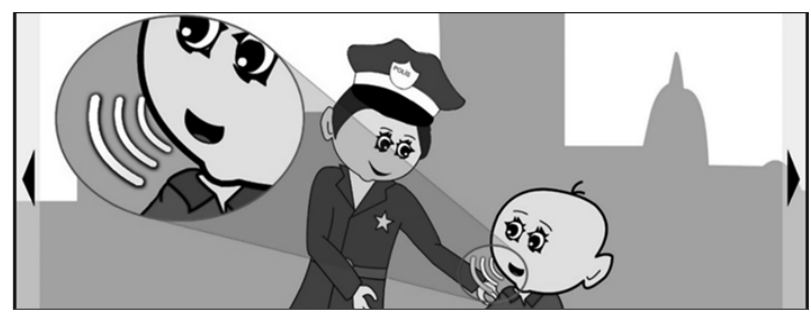

Figure 8. The demonstration in the "Aliş Kayboldu" (Aliş Gets Lost) animation for the act of "speaking"

In the third-round revisions, it was reported that the use of punctuation marks in the sentences that appear in the animations would be beneficial within the framework of the feedback received after the applications conducted on 17.11.2014. The researchers expressed this situation in the observation notes regarding the relevant change suggestions as follows:

"T1 reported that punctuation marks should be provided - Punctuation marks suitable for Turkish writing should be used." (Observation date: 17.11.2014)

These suggestions were reviewed by the evaluation group and punctuation marks such as full stops, commas and question marks were used in the sentences used in the animations. For example, the punctuation marks in the "Toprak, su, hava cansızdır" (Earth, water, and air are inanimate) sentence in the "Cansız Nesneler" (Inanimate Objects) animation are shown in Figure 9.

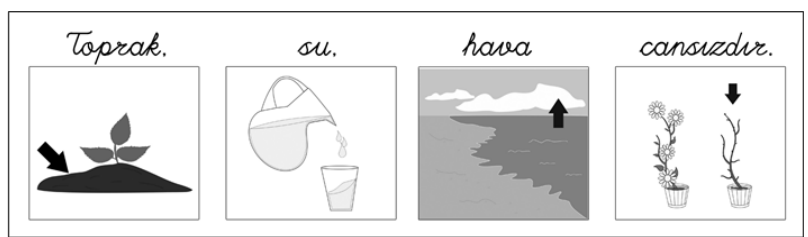

Figure 9. Sample application for the demonstration of punctuation marks 
In the fourth-round revisions, it was reported that long and complicated sentences used in animations in the scope of the practices carried out on 18.11.2014 led to distractedness and that rather than these types of uses, sentences should be used by being divided into two. The change recommendation that $\mathrm{T} 2$ specified was noted by the researchers, as seen in Figure 10, following the scenario study of the relevant application ("Cümle ikiye bölünecek. Bu halinin uzun olduğu söylendi". In English, "The sentence will be divided into two. It was said that this version was long").

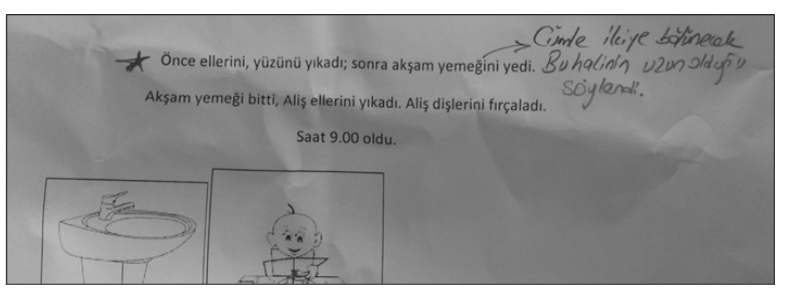

Figure 10. Researchers' notes on the scenario for the animation

The sentence, "Önce ellerini, yüzünü yıkadı; sonra akşam yemeğini yedi" (in English: "First he washed his hands and face, then he ate dinner") recommended to be divided into two by $T 2$ in the "Aliş Evde" (Aliş at Home) animation was rearranged by the evaluation group. In this scope, by dividing the sentence into two parts without creating a change in the flow of the story, it was used in the form of "Önce ellerini, yüzünü yıkadı." (in English: "He first washed his hands and face") and "Sonra akşam yemeği yedi." (in English: "Then he ate dinner"). Figure 11 presents animation screenshots for the conducted changes. Care was shown not to use sentences longer than six words in the stories created after this date.

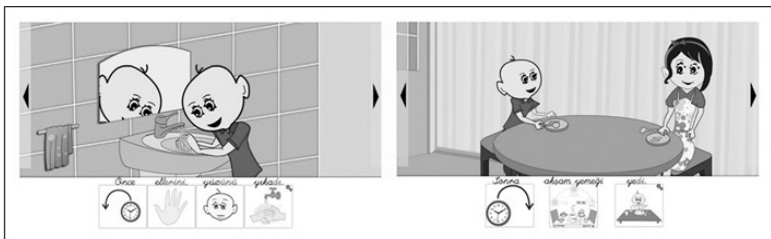

Figure 11. The demonstration of the sentence "Önce ellerini, yüzünü yıkadı; sonra akşam yemeğini yedi." (in English: "First he washed his hands and face, then he ate dinner") in the animation as two separate sentences.

The fifth round of revision was carried out on the basis of the feedback received within the scope of the practices carried out on 17.12.2014. In the observation notes of the researchers it was stated that it would be useful if the drawings in the animations were paired with the graphic symbol glossary:

"For some verbs, the students cannot fully understand the drawings made in the animations. The teachers expect the motions in the animation to be like, or at least resemble, the drawings in the graphic symbol dictionary." (Observation date: 17.12.2014)

Incoming suggestions were examined by the evaluation group and suggestions were given to the designers in order to draw the drawings used in the animations in a way similar to the drawings in the graphic symbols. In accordance with these suggestions, a revision study (Figure 12) was made for the word "düşündü" ("thinking") in the relevant story. When Figure 12 is examined, the provision in the graphic symbol dictionary for the word "düşündü" is seen in the lower section of the screen. The environment in which the character is depicted in the animation is designed in a similar way to the "thinking" graphic symbol. Attention was paid to use of designs similar to the graphics in the graphic symbol dictionary in the animations developed after this date.

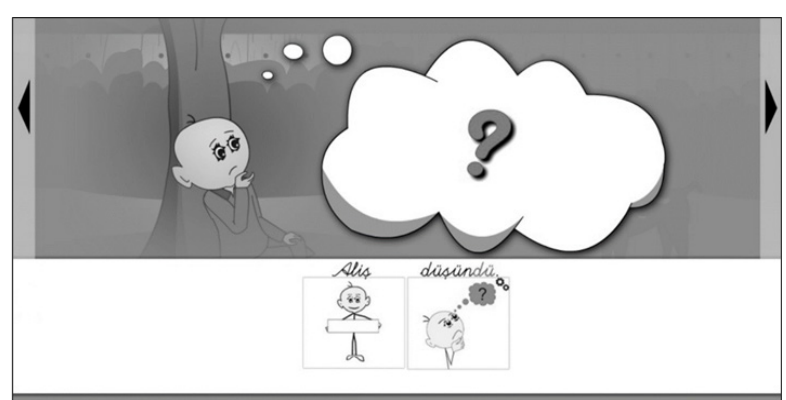

Figure 12. The change in animation for the word "thinking" ("düşündü").

The sixth-round revision studies were conducted in line with the requests of the implementing classroom teachers for the use of sound in the animations in the applications conducted on 24.03.2015. T1's views regarding the use of sound in animations are as follows.

"I think it is necessary to add environmental sounds like a dog barking for giving a sense of fear and a shutter sound when taking pictures, because while students are watching animations with sound effects, they are happier and they can better understand the situation." (T1 - 24.03.2015)

The evaluation group evaluated the feedback from the implementing teachers and environmental sounds were added to the animations. Environmental sounds continued to be added in the subsequent animations. In the interviews held on 07.05.2015, the reason why it was necessary to add sound in the animations was expressed by $\mathrm{T} 1$ and $\mathrm{T} 2$ as:

"I had wanted you to add sounds to use residual listening, and thank you for adding them. Sound effects are required in animation for listening training." (T1 - 07.05.2015)

"From now on, students with cochlear implants will come. With the new generation of cochlear implants, sound effects are important." (T2 - 07.05.2015).

The seventh-round revision covers the evaluations made by the evaluation group for the applications carried out throughout the period. Throughout the applications, the environments for the animation $(A)$, animation and text $(A+$ $T)$, and animation, text and graphic symbol $(A+T+G)$ were combined in a single environment. In this way, the teacher can grant the students the right of selection during the application of the animations. In this respect, Figure 13 presents the revised form of the spatial design characteristics for the objects to be used in the animations.

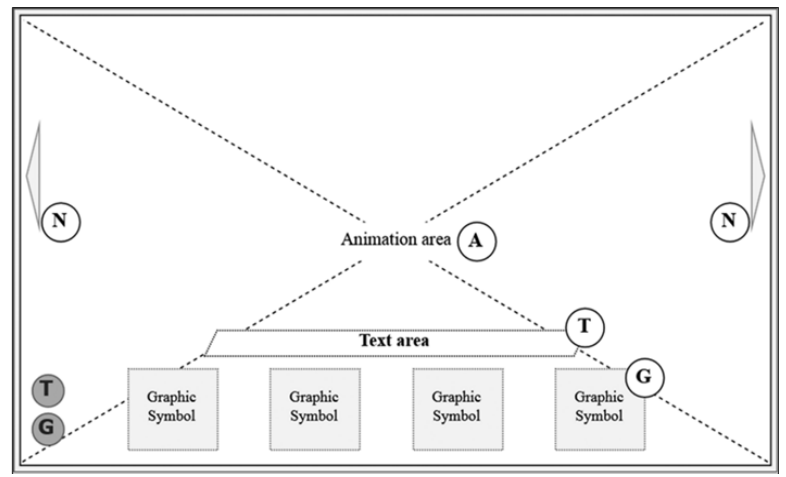

Figure 13. The revised form of the spatial design characteristics for the objects to be used in the animations.

When Figure 13 is examined, it is seen that the initial positions of the animations $(A)$, texts $(T)$, and graphic symbols (G) have not changed. Besides this, however, the navigation (N) button, that allows the pause to be consciously guided 
forward or backward after each sentence in the animations, was added to the right (forward) and left (backward) sides of the screen after the revisions. Also, the T (Text) and G (Graphic symbol) buttons on the left side of the screen make it possible to use the $A, A+T$ and $A+T+G$ environments which were used separately in the first applications. Figure 14 presents a screenshot for the "Test" application regarding the final version of the revisions made in the animation.

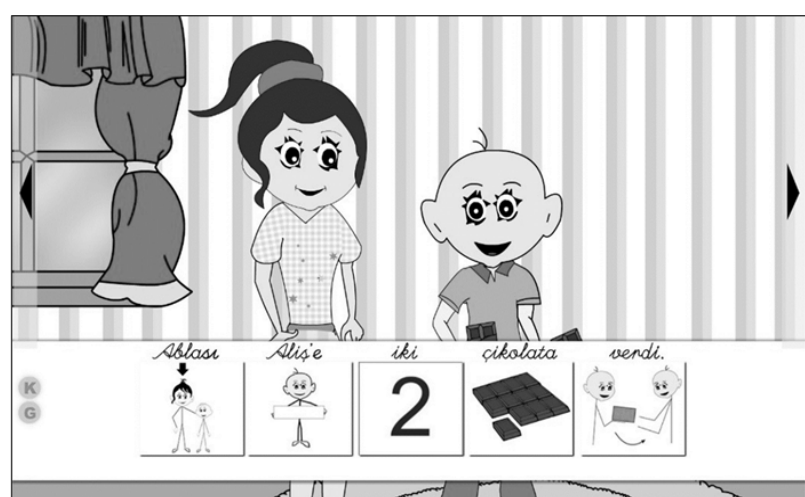

Figure 14. The unification in a single material of the animations developed as three different materials.

The revisions made in light of the data acquired during the application process were implemented retrospectively for all the animations developed. In this way, an open platform (www. alis.org.tr) is provided to all users to access the animations which are provided in a standard view. In this scope, the characteristics that graphic symbol based animations should have and the points that should be taken into consideration in the application can be summarised as in Table 6 .

Table 6. The characteristics that animations based on graphic symbols should possess

\begin{tabular}{|c|c|}
\hline Characteristics & Application Style \\
\hline Simple designs & $\begin{array}{l}\text { Objects that are small, eye-straining or func- } \\
\text { tionless in the background should not be used. }\end{array}$ \\
\hline \multirow{4}{*}{ Standard drawings } & $\begin{array}{l}\text { The drawings of frequently used actions should } \\
\text { be standardised. }\end{array}$ \\
\hline & $\begin{array}{l}\text { Standard designs should be made that express } \\
\text { that the character is speaking in the animation. }\end{array}$ \\
\hline & $\begin{array}{l}\text { The drawings used in the animations should be } \\
\text { standardised. }\end{array}$ \\
\hline & $\begin{array}{l}\text { Animation drawings should be consistent with } \\
\text { the graphic symbol system used. }\end{array}$ \\
\hline $\begin{array}{l}\text { Suitability for the } \\
\text { student }\end{array}$ & $\begin{array}{l}\text { The writing font used in the animation should } \\
\text { suit the writing style of the student. }\end{array}$ \\
\hline \multirow{2}{*}{$\begin{array}{l}\text { Short and simple } \\
\text { sentences }\end{array}$} & $\begin{array}{l}\text { Punctuation marks should be provided in the } \\
\text { texts used in the animation. }\end{array}$ \\
\hline & $\begin{array}{l}\text { Sentences should be composed of at most six } \\
\text { words. }\end{array}$ \\
\hline \multirow{3}{*}{$\begin{array}{l}\text { Avoiding complicat- } \\
\text { ed explanations }\end{array}$} & Long flows of events should be divided. \\
\hline & $\begin{array}{l}\text { Each of the words that make up the sentence } \\
\text { should be presented together with the relevant } \\
\text { graphic symbol. }\end{array}$ \\
\hline & $\begin{array}{l}\text { There should be an explicit provision in the } \\
\text { animation for each sentence in the story. }\end{array}$ \\
\hline \multirow{2}{*}{$\begin{array}{l}\text { Providing sound } \\
\text { support }\end{array}$} & $\begin{array}{l}\text { Sound effects and speaking sounds should be } \\
\text { used in the animations for residual hearing. }\end{array}$ \\
\hline & $\begin{array}{l}\text { Environmental sounds should be added (e.g., } \\
\text { timer, dog bark, walking). }\end{array}$ \\
\hline $\begin{array}{l}\text { Opportunity for } \\
\text { interactive use }\end{array}$ & $\begin{array}{l}\text { The choice of text and graphic symbol support } \\
\text { in the animation should be left to the user } \\
\text { during the application. }\end{array}$ \\
\hline
\end{tabular}

\section{Discussion and Conclusion}

It is known that the educational problems that $\mathrm{D} / \mathrm{HH}$ students experience lead to their encountering difficulties in establishing a relationship between written materials and visuals (Nikolaraizi et al., 2013). It is stated that the use of enriched educational environments in addition to pictures and texts will be useful for the learning of D/HH students (Debevc et al., 2010; Zainuddin et al., 2010). It is stated that interactive multimedia applications increase the learning potential of students in literacy and vocabulary learning studies (Şılbır, 2011; Doğan \& Akdemir, 2015; Yovkova, 2010). At this point, since the attention of $\mathrm{D} / \mathrm{HH}$ students to their environment is visually based, it is seen as a necessity to investigate the characteristics of the materials to be developed in order for the visuals that will be presented to the students in educational environments to be effective (Doğan \& Akdemir, 2015; Ünlüer, 2010). It is emphasised that the materials to be prepared for D/HH students should be visually rich and supported with different resources related to the course outcomes of the students (Reitsma, 2009).

When the animation development studies conducted for the educational environments of $\mathrm{D} / \mathrm{HH}$ students are examined, it is generally seen that they are studies for the animation of sign language (Kaneko et al., 2010; Kipp, Heloir, \& Nguyen, 2011; Kourbetis, 2013; Verlinden, Zwitserlood, \& Frowein, 2005). However, there are also studies developed with the name of the learning environment or cartoons which contain animations (Cambra et al., 2014; Debevc et al., 2010; Lányi et al., 2004; Petrie et al., 2005; Verlinden et al., 2005; Zainuddin et al., 2010). In the studies examined, it is seen that features such as using simple designs, supporting with text, presenting short event streams, and using text and image together are discussed in the scope of different studies in the animations developed for the $\mathrm{D} / \mathrm{HH}$ students. At this point, it is crucial to determine the types of components to be developed for D/ $\mathrm{HH}$ students and the characteristics of these components. In addition, no graphic symbol based animation system was observed in the examinations made. Based on the findings obtained in the current research into a graphic symbol supported animation system developed for use in the literacy education of D/HH students, it was determined that text, graphic symbols, animation, buttons that make text or graphic symbols visible or hidden, sound, and forward-backward navigation buttons should be included.

It was reported, in the environment that Zainuddin et al. (2010) developed with the support of elements with increased authenticity with reference to the need of $\mathrm{D} / \mathrm{HH}$ students to learn visually, that graphics needed to be colourful and composed of simple drawings, that the texts needed to be supposed with brief and suitable graphics, and that texts, pictures, sign language, and 3D models could be used together. The current study reveals similar research results. The conclusion was reached that simple designs needed to be made by avoiding small-scale drawings with no connection to the subject flow or story contents found in the background in the animation designs. It is seen that the characteristics specified in the scope of the research were handled separately in different studies. Lányi et al. (2004) report that the use of simple rather than professional designs is more convenient for D/ $\mathrm{HH}$ students. The elements that distracted the students were removed from the environment in this respect. Also, at the point of presenting the texts with short and suitable graphics, all the sentences found in the conducted study are composed of at most six words, and the provision of a graphic symbol is presented together with a word. It is known that it provides better results to use words together with visuals compared with only the use of words (Gentry et al., 2004). Animations, graphic symbols, texts, and sound effects were used together in the study. It is found in different studies that the use of dif- 
ferent combinations of text, images, sign language, sound, and 3-dimensional models in the same setting is effective for D/HH students (Debevc et al., 2010; Petrie et al., 2005; Zainuddin et al., 2010). However, different from the examined studies, the graphic symbols and subtitles in this study were independently addable to, or removable from, the environment. In this respect, environments can be created that allow students to occasionally conduct activities in the in-class applications such as matching and writing with uses such as animation only, animation+graphic symbol, or animation+text.

Many previous studies state that the support of subtitles provides a supportive characteristic in the definition of words that cannot be perceived through auditory methods for $\mathrm{D} / \mathrm{HH}$ students whose native language is not the language presented in the materials (Cambra et al., 2014; Debevc et al., 2010; Petrie et al., 2005). Subtitles were added to the environment as a supportive element in the study. However, it was reported that subtitles needed to vary with the current writing styles of the D/HH students.

Another notable point made by the researchers was that it was necessary for each sentence to be found explicitly in the animations that would be presented to $\mathrm{D} / \mathrm{HH}$ students so that the D/HH students could extract meaning from the relevant sentence. At this point, the flow of events in animations or cartoons prepared for $\mathrm{D} / \mathrm{HH}$ students can lead to a loss of the goals to which educational importance needs to be attached. For example, if three different situations are desired to be given within an animation, there is the possibility that the student will notice only one and not notice the other two situations at the end of this animation. For this reason, the presentation by pausing the animations prepared allows the student to evaluate each pause as a new situation. The forward and backward buttons fixed on the right and left sides of the screen are navigated after stops. When examined from a schematic perspective, it is recommended that the placement of the navigation buttons should be fixed (Debevc et al., 2010). Since it provides ease of use in the literature, it is possible to say that the navigation buttons that are valued, contribute to the meaning of a story presented with animation.

As a result, the animations based on graphic symbols planned to be used in the literacy education of D/HH students should have simple designs that are cleansed of long sentences and that do not contain confusing drawings. The presentation with the same standard of the verbs used frequently in the animations helps the story to flow steadily. Another situation is that in the teaching of abstract or long words, these concepts should be emphasised numerous times in the animations. A previously conducted study emphasised that the number of new words in the text of a story that D/HH students newly encounter should be limited to 3-4 words (Lányi et al., 2004). It is clear that helping D/HH students who are unable to efficiently use auditory channels because of hearing loss to effectively use visual channels will contribute to the education of these students. By conducting constant revision operations in the scope of the applications, an attempt was made to obtain designs that best suit the $\mathrm{D} / \mathrm{HH}$. Considering the characteristics possessed by the materials that emerged as a result of these studies, it is seen that animations, graphics, symbols, and words can be presented at the same time to $\mathrm{D} / \mathrm{HH}$ students.

\section{Recommendations}

It is essential to work together with the teachers to consider the individual characteristics of D/HH students in the process of developing materials to be used in the educational environments for these students. In the development of these types of materials, it is seen as important for there to be an educational technologist who will work together with the teachers in terms of the applicability of the design criteria.

It is reported in studies conducted with hearing individuals in the literature that information presented to students via both visual and auditory channels is more beneficial than information presented by means of only auditory or only visual channels (Moreno \& Mayer, 1999). It was inevitable that these studies conducted with hearing individuals would produce different results to those for $\mathrm{D} / \mathrm{HH}$ students. For this reason, research can be conducted with different studies towards the identification of visual channel capacities for the use of visual channels by D/HH students.

\section{Funding}

This work was supported by TUBITAK under Grant Number 113 K717.

\section{References}

Amiel, T., \& Reeves, T. C. (2008). Design-Based Research and Educational Technology: Rethinking Technology and the Research Agenda. Journal of Educational Technology \& Society, 11(4), 29-40. Retrieved from http:// www.jstor.org/stable/jeductechsoci.11.4.29

Akmeşe, P., Sezgin, D., \& Öğüt, F. (2019). Investigation of Early Literacy Skills in Preschool Children With Deaf and Hard of Hearing. International Electronic Journal of Elementary Education, 12(2), 137-143. Retrieved from https://iejee.com/index.php/IEJEE/article/view/916

Akay, E., Uzuner, Y., \& Girgin, Ü. (2014). Kaynaştırmadaki işitme engelli öğrencilerle gerçekleştirilen destek eğitim odası uygulamasındaki sorunlar ve çözüm gayretleri. Eğitimde Nitel Araştırmalar Dergisi, 2(2), 4368.

Bowers, L. M., Dostal, H., Wolbers, K. A., \& Graham, S. C. (2018). The assessment of written phrasal constructs and grammar of Deaf and Hard of Hearing Students with varying expressive language abilities. Education Research International, 1-10. doi: $10.1155 / 2018 / 2139626$

Brantlinger, E., Jimenez, R., Klingner, J., Pugach, M., \& Richardson, V. (2005). Qualitative studies in special education. Exceptional children, 71(2), 195-207. doi:10.1177/001440290507100205.

Büyüköztürk, Ş., Kılıç-Çakmak, E., Akgün, Ö.E., Karadeniz, Ş., \& Demirel, F. (2014). Bilimsel araştırma yöntemleri. Ankara: Pegem Akademi.

Cambra, C., Penacchio, O., Silvestre, N., \& Leal, A. (2014). Visual attention to subtitles when viewing a cartoon by deaf and hearing children: an eye-tracking pilot study. Perspectives, 22(4), 607-617. doi:10.1080/0907 676X.2014.923477.

Cavkaytar, A., \& Diken, i̇. H. (2005). Özel eğitime giriş. Ankara: Kök.

Chen, Y. T. (2014). A study to explore the effects of self-regulated learning environment for hearing-impaired students. Journal of Computer Assisted Learning, 30(2), 97-109. doi:10.1111/jcal.12023. 
Cruz, D. M. (2013). Instructional design strategies used to provide equal learning opportunity for deaf and hard of hearing learners (Doctoral dissertation). Capella University, US.

Cole, K. M., Cutler, M. M., Thobro, P., \& Haas, R. (2009). An exploratory study of psychosocial risk behaviors of adolescents who are deaf or hard of hearing: Comparisons and recommendations. American Annals of the Deaf, 154(1), 30-35. doi:10.1353/aad.0.0074.

Collins, A., Joseph, D. and Bielaczyc, K. (2004). Design research: Theoretical and methodological issues. The Journal of The Learning Sciences, 13(1), 15-42.

Debevc, M., Kosec, P., \& Holzinger, A. (2010). E-learning accessibility for the deaf and hard of hearing-practical examples and experiences. Invited symposium presentation, Symposium of the Austrian $\mathrm{HCl}$ and Usability Engineering Group (203-213). Springer, Berlin, Heidelberg, November.

Denzin, K.N. \& Lincoln S.Y. (2000). Handbook of Qualitative Research. New Delhi: Sage.

Dillon, C. M., de Jong, K., \& Pisoni, D. B. (2012). Phonological awareness, reading skills, and vocabulary knowledge in children who use cochlear implants. Journal of Deaf Studies and Deaf Education, 17(2), 205-226. doi:10.1093/deafed/enr043.

Doğan, İ., \& Akdemir, Ö. (2015). Özel Eğitimde Bilgisayar Destekli Öğretim: Üç Durum Çalışması. Journal of High er Education \& Science/Yüksekögretim ve Bilim Dergisi, 5(2), 165-177. doi:10.5961/jhes.2015.119.

Ellis, K., \& Kent, M. (2011). Disability and new media. New York: Routledge.

Foley, A., \& Ferri, B. A. (2012). Technology for people, not disabilities: Ensuring access and inclusion. Journal of Research in Special Educational Needs, 12(4), 192-200. doi:10.1111/j.1471-3802.2011.01230.x.

Fuller, D., \& Lloyd, L. (1991). Toward a common usage of iconicity terminology. Augmentative and Alternative Communication, 7(3), 215-220. doi:10.1080/07434619 112331275913

Gatti, N., Matteucci, M., \& Sbattella, L. (2004). An adaptive and predictive environment to support augmentative and alternative communication. Invited symposium presentation, International Conference on Computers for Handicapped Persons (pp. 983-990). Springer, Berlin, Heidelberg, July.

Gentry, M. M., Chinn, K. M., \& Moulton, R. D. (2004). Effectiveness of multimedia reading materials when used with children who are deaf. American Annals of the Deaf, 149(5), 394-403. doi:10.1353/aad.2005.0012.

Hoffman, M., \& Wang, Y. (2010). The use of graphic representations of sign language in leveled texts to support deaf readers. American Annals of The Deaf, 155(2), 131-136. doi:10.1353/aad.2010.0002

ISO 17724:2003 (2003), Graphical symbols - Vocabulary. Retrieved from International Organization for Standardisation (ISO). 01.080.10.

Jemni, M., Elghoul, O., \& Makhlouf, S. (2007). A web-based tool to create online courses for deaf pupils. Invited symposium presentation, International conference on interactive mobile and computer aided learning (18-20), Amman, Jordan, April.
Jensema, C. J., Danturthi, R. S., \& Burch, R. (2000). Time spent viewing captions on television programs. American Annals of The Deaf 145(5), 464-468. doi:10.1353/ aad.2012.0144

Kaneko, H., Hamaguchi, N., Doke, M., \& Inoue, S. (2010,). Sign language animation using TVML. Invited symposium presentation, Proceedings of the 9th ACM SIGGRAPH Conference on Virtual-Reality Continuum and its Applications in Industry (289-292). Seoul, South Korea, December.

Karal, H. ve Çiftçi, E. (2008, Eylül). Işitme engelli bireylerin eğitim sürecinde bilgisayar destekli animasyonlardan yararlanma. 8. Uluslararası Eğitim Teknolojileri Konferansı'nda sunulan bildiri (IETC), Anadolu Üniversitesi, Eskişehir.

Kipp, M., Heloir, A., \& Nguyen, Q. (2011). Sign language avatars: Animation and comprehensibility. Invited symposium presentation,10th International Workshop on Intelligent Virtual Agents. Reykjavik, Iceland, September.

Kourbetis, V. (2013). Design and development of accessible educational and teaching material for deaf students in Greece. Invited symposium presentation, International Conference on Universal Access in Human-Computer Interaction (172-178). Springer, Berlin, Heidelberg, July.

Kuzu, A., Çankaya, S. ve Mısırlı, Z. A. (2011). Tasarım tabanIı araştırma ve öğrenme ortamlarının tasarımı ve geliştirilmesinde kullanımı. Anadolu Journal of Educational Sciences International, 1(1), 19-35.

Kyle F. E. and Harris M. (2006). Concurrent correlates and predictors of reading and spelling achievement in deaf and hearing school children. Journal of Deaf Studies and Deaf Education, 11, 273-288.

Lányi, C.S., Váry, Á., Sik, A., Nemetz A., \& Geiszt Z. (2004). Multimedia programs for children with hearing difficulties. Invited symposium presentation. International Conference on Computers for Handicapped Persons (14-21). Springer, Berlin, Heidelberg, July.

Lederberg, A. R., Schick, B., \& Spencer, P. E. (2013). Language and literacy development of deaf and hard-of-hearing children: Successes and challenges. Developmental Psychology, 49(1), 15-30. doi:10.1037/a0029558

Luckner, J. L., \& Cooke, C. (2010). A summary of the vocabulary research with students who are deaf or hard of hearing. American Annals of the Deaf, 155(1), 38-67. doi:10.1353/aad.0.0129.

Marschark, M., Sapere, P., Convertino, C., Mayer, C., Wauters, L., \& Sarchet, T. (2009). Are deaf students' reading challenges really about reading? American Annals of the Deaf, 154(4), 357-370. doi:10.1353/aad.0.0111.

Marschark, M., \& Knoors, H. (2012). Educating deaf children: Language, cognition, and learning. Deafness \& Education International, 14(3), 136-160.

Mayer, R. E., \& Moreno, R. (2003). Nine ways to reduce cognitive load in multimedia learning. Educational Psychologist, 38(1), 43-52. doi:10.1207/S15326985EP3801_6.

MEB (2006).Türk Işaret Dili Sisteminin uygulanmasına yönelik usul ve esasları belirlemeye ilişkin yönetmelik. Retrieved from Ministry of National Education, Republic of Turkey. 
Mollink, H., Hermans, D., \& Knoors, H. (2008). Vocabulary training of spoken words in hard-of-hearing children. Deafness \& Education International, 10(2), 80-92. doi:10.1002/dei.240.

Moreno, R., \& Mayer, R. E. (1999). Cognitive principles of multimedia learning: The role of modality and contiguity. Journal of educational psychology, 91(2), 358368. doi:10.1037/0022-0663.91.2.358.

Nikolaraizi, M., \& Vekiri, I. (2012). The design of a software to enhance the reading comprehension skills of deaf students: An integration of multiple theoretical perspectives. Education and Information Technologies, 17(2), 167-185. doi:10.1007/s10639-011-9152-1.

Nikolaraizi, M., Vekiri, I., \& Easterbrooks, S. (2013). Investigating deaf students' use of visual multimedia resources in reading comprehension. American Annals of the Deaf, 157(5), 458-473. doi:10.1353/aad.2013.0007.

Patton, M. (2014). Nitel araştırma ve değerlendirme yöntemleri. (Bütün, M., \& Demir, S.B.). Ankara, Pegem.

Paudyal, P., Banerjee, A., Hu, Y., \& Gupta, S. (2019, June). DAVEE: A Deaf Accessible Virtual Environment for Education. In Proceedings of the 2019 on Creativity and Cognition (pp. 522-526). ACM.

Petrie, H. L., Weber, G., \& Fisher, W. (2005). Personalisation, interaction, and navigation in rich multimedia documents for print-disabled users. IBM Systems Journal, 44(3), 629-635. doi:10.1147/sj.443.0629.

Pınar, E. G. E. (2006). Farklı engel gruplarının iletişim özellikleri ve öğretmenlere öneriler. Ankara Üniversitesi Ĕ̆itim Bilimleri Fakültesi Özel Ĕğtim Dergisi, 7(2), 1-23. doi:10.1501/Ozlegt_0000000099.

Pugach, M. C. (2001). The stories we choose to tell: Fulfilling the promise of qualitative research for special education. Exceptional Children, 67(4), 439-453. doi:10.1177/001440290106700401.

Reitsma, P. (2009). Computer-Based Exercises for Learning to Read and Spell by Deaf Children. The Journal of Deaf Studies and Deaf Education, 14(2), 178-189, doi:10.1093/deafed/enn031.

Rudner, M., Andin, J., Rönnberg, J., Heimann, M., Hermansson, A., Nelson, K., \& Tjus, T. (2015). Training literacy skills through sign language. Deafness \& Education International, 17(1), 8-18.

Scott, J. A., \& Dostal, H. M. (2019). Language Development and Deaf/Hard of Hearing Children. Education Sciences, 9(2), 135.

Scott, J.A., Goldberg, H., McDonald Connor, C., \& Lederberg, A.R. (2019). Schooling Effects on Early Literacy Skills of Young Deaf and Hard of Hearing Children. American Annals of the Deaf 163(5), 596-618. doi:10.1353/ aad.2019.0005.

Singh, R. K., \& Mahapatra, S. K. (2019). Education of Deaf Learners through Open Schooling System in India. Asian Journal of Distance Education, 14(2), 26-31. Retrieved from http://www.asianjde.org/ojs/index. php/AsianJDE/article/view/420

Snoddon, K. (2010). Technology as a Learning Tool for ASL Literacy. Sign Language Studies, 10(2), 197-213. Retrieved from http://www.jstor.org/stable/26190568.
Stoner, J.B. (2010) Qualitative Research In Education: Other Methods Of Seeking Knowledge, In Obiakor, F. E., Bakken, J. P., \& Rotatori, A. F. (Eds.). Current issues and trends in special education: Research, technology, and teacher preparation (19-39). Emerald Group Publishing.

Şılbır, L. (2011). Işitme engelli öğrencilerin Türkçe okuma yazma becerilerinin geliştirilmesine yönelik görsel yardım paketi: GÖRYAP. (Unpublished master's dissertation). Karadeniz Technical University, Turkey. Retrieved from https://tez.yok.gov.tr/UlusalTezMerkezi/

Talaván, N. (2019). Using subtitles for the deaf and hard of hearing as an innovative pedagogical tool in the language class. International Journal of English Studies, 19(1), 21-40. https://doi.org/10.6018/ijes.338671

Techaraungrong, P., Suksakulchai, S., Kaewprapan, W., \& Murphy, E. (2017). The design and testing of multimedia for teaching arithmetic to deaf learners. $E d-$ ucation and Information Technologies, 22(1), 215-237. doi:10.1007/s10639-015-9441-1.

The Design-Based Research Collective. (2003). Design-based research: An emerging paradigm for educational inquiry. Educational Researcher, 32(1), 5-8.

Tolar, T. D., Lederberg, A. R., Gokhale, S., \& Tomasello, M. (2008). The development of the ability to recognize the meaning of iconic signs. Journal of Deaf Studies and Deaf Education, 13(2), 225-240.

Trudeau, N., Sutton, A., Dagenais, E., De Broeck, S., \& Morford, J. (2007). Construction of graphic symbol utterances by children, teenagers, and adults: The effect of structure and task demands. Journal of Speech, Language, and Hearing Research, 50(5), 1314-1329.

Tucker Cohen, E., Allgood, M., Wolff Heller, K., \& Castelle, M. (2001). Use of picture dictionaries to promote written communication by students with hearing and cognitive impairments. Augmentative and Alternative Communication, 17(4), 245-254. doi:10.1080/ aac.17.4.245.254.

Turnbull, A., Turnbull, H. R., Wehmeyer, M. L., \& Shogren, K. A. (2013). Exceptional lives: Special education in today's schools. Columbus, $\mathrm{OH}$ : Pearson.

Tüfekçioğlu, Ü. (1998). Özel Eğitim Kitabı Ünite 8. Ankara. Türkiye Cumhuriyeti Anadolu Üniversitesi Yayınları.

Türköz Sarp. F. (2013). Iş̧itme engelli bireylerde görsel algI (master's thesis). Arel University, Turkey.

Ünlüer, S. (2010). Engelliler entegre yüksek okulundaki bilgi ve iletişim teknolojileri entegrasyonu sürecinin incelenmesi (doctoral dissertation). Anadolu University, Turkey.

Véliz, S., Espinoza, V., Sauvalle, I., Arroyo, R., Pizarro, M., Escobar, P. and Garolera, M. (2016). Towards a participative approach for adapting multimodal digital books for deaf and hard of hearing people. International Journal of Child-Computer Interaction, 11, 90-98.

Verlinden, M., Zwitserlood, I., \& Frowein, H. (2005). Multimedia with animated sign language for deaf learners. Invited symposium presentation, EdMedia: World Conference on Educational Media and Technology (4759-4764). Association for the Advancement of Computing in Education (AACE), Viataal, Netherlands, June. 
Yovkova, B. S. (2010). Interactive Instructional Multimedia in Vocabulary Development of Children With Hearing Loss, Invited symposium presentation, International Conference ICT For Language Learning 3rd. Edition. Florence, Italy, November.

Zainuddin, N. M. M., Zaman, H. B., \& Ahmad, A. (2010). A participatory design in developing prototype an augmented reality book for deaf students. Invited symposium presentation, Second International Conference on Computer Research and Development, Kuala Lumpur, Malaysia, May. 